\title{
Peningkatan Keterampilan Berbicara Mahasiswa melalui Praktik Berpidato dan Praktik Bercerita Menggunakan Video Pembelajaran Praktik Berbicara
}

\author{
Agus Joko Purwadi \\ (corresponding author) \\ Program Studi Pendidikan Bahasa Indonesia, Universitas Bengkulu \\ Email: agusjokop2808@unib.ac.id \\ Didi Yulistio \\ Program Studi Pendidikan Bahasa Indonesia, Universitas Bengkulu \\ Email: yulistiodidi@unib.ac.id \\ Rio Kurniawan \\ Program Studi Pendidikan Bahasa Indonesia, Universitas Bengkulu \\ Email: kurniawan22rio@yahoo.com
}

\begin{abstract}
APA Citation: Purwadi, A. J., Yulistio, D., \& Kurniawan, R. (2021). Peningkatan Keterampilan Berbicara Mahasiswa melalui Praktik Berpidato dan Praktik Bercerita Menggunakan Video Pembelajaran Praktik Berbicara. Silampari Bisa: Jurnal Penelitian Pendidikan Bahasa Indonesia, Daerah, dan Asing, 4(2), 373-397. https://doi.org/10.31540/silamparibisa.v4i2.1480
\end{abstract}

\begin{abstract}
Abstrak
Tujuan penelitian ini untuk mendeskripsikan peningkatan keterampilan berbicara melalui praktik berpidato dan praktik berbicara menggunakan video pembelajaran daring pada mahasiswa Prodi S-1 Pendidikan Bahasa Indonesia, FKIP Universitas Bengkulu. Penelitian ini menggunakan prosedur PTK model Hopkins yang ditempuh dalam dua siklus. Setiap siklus dilaksanakan melalui empat tahapan, meliputi tahap perencanaan, tahap tindakan, tahap pengamatan, dan tahap refleksi. Sumber data penelitian ini mahasiswa S-1 Pendidikan Bahasa Indonesia semester genap 2020-2021 sebanyak 40 orang. Data penelitian berupa penampilan praktik berpidato dan bercerita dalam video praktik pembelajaran. Pengumpulan data menggunakan teknik tes berbicara dengan cara praktik berpidato dan bercerita dan teknik pengamatan untuk mengamati aktivitas mahasiswa dalam proses pembelajaran daring. Analisis data menggunakan rumus rerata dan hasil akhir secara kualitatif. Hasil penelitian menunjukkan bahwa terjadi peningkatan keterampilan berbicara mahasiswa yang dilakukan dengan cara praktik berpidato dan praktik bercerita melalui pemanfaatan video pembelajaran daring. Hal ini dibuktikan dari proses dan hasil pembelajaran pada siklus I dengan rerata skor sebesar 75,6 kategori baik, meningkat pada siklus II dengan skor sebesar 85,8 berkategori sangat baik. Peningkatan keterampilan berbicara ini diikuti dengan meningkatnya aktivitas mahasiswa dalam proses pembelajaran pada siklus I dengan kategori sikap aktif dengan rerata 4,28 meningkat pada siklus II menjadi sangat aktif dengan rerata 4,72, dalam sikap disiplin, tanggung jawab, bekerja sama (berkolaborasi), kemandirian, dan kejujuran semuanya berkategori sangat aktif.
\end{abstract}

Kata kunci: berbicara, praktik berpidato, praktik bercerita, video pembelajaran 
Agus Joko Purwadi, Didi Yulistio, Rio Kurniawan

Peningkatan Keterampilan Berbicara Mahasiswa melalui Praktik Berpidato dan Praktik Bercerita Menggunakan Video Pembelajaran Praktik Berbicara

\title{
Improvement of Student's Speaking Skills through Spreading Practices and Storyling Practices Using Speaking Practical Learning Videos
}

\begin{abstract}
The purpose of this study was to describe the improvement of speaking skills through speech practice and speaking practice using online learning videos for students of the Indonesian Language Education Study Program, Faculty of Teacher Training and Education, Bengkulu University. This research uses the Hopkins CAR procedure which is taken in two cycles. Each cycle is carried out through four stages, including the planning stage, the action stage, the observation stage, and the reflection stage. The data sources for this research were 40 students of S1 Indonesian Language Education in the even semester of 2020-2021. The research data is in the form of performances in the practice of making speeches and telling stories in learning practice videos. Collecting data using speaking test techniques by way of practicing speeches and storytelling and observation techniques to observe student activities in the online learning process. Data analysis used the mean formula and qualitative final results. The results showed that there was an increase in students' speaking skills which was carried out by practicing speeches and practicing storytelling through the use of online learning videos. This is evidenced by the process and learning outcomes in the first cycle with an average score of 75.6 in the good category, increasing in the second cycle with a score of 85.8 in the very good category. This improvement in speaking skills was followed by an increase in student activity in the learning process in the first cycle with an active attitude category with an average of 4.28 increasing in the second cycle to being very active with an average of 4.72 , in discipline, responsibility, working together (collaborating), independence, and honesty are all categorized as very active.
\end{abstract}

Keywords: speaking, speech practice, storytelling practice, learning video

\section{A. Pendahuluan}

Praktik pembelajaran yang berhasil bukan hanya ditentukan oleh pembelajar dan pengajar, tetapi juga didukung dengan kondisi dan situasi berlangsungnya kegiatan pembelajaran serta sistem pengelolaan kegiatan pembelajaran yang digunakan. Saat ini, karena kondisi dan situasi yang tidak normal maka sistem pengelolaan kegiatan pembelajaran dilaksanakan melalui dua cara, yakni cara tatap muka (luring) dan cara nontatap muka atau tatap maya (daring). Pembelajaran daring dilakukan karena kondisi tertentu, seperti adanya pandemi Covid-19 (saat ini belum norma) yang mempengaruhi kesehatan tubuh manusia. Sehingga manusia harus berhati-hati dan disiplin dalam menjaga kesehatan dirinya dan orang lain dengan taat menjalankan sistem protokol kesehatan, seperti menjaga jarak, mencuci tangan, dan memakai masker agar terhindar dari penyebaran virus antarmanusia. Dengan kata lain, pembelajaran daring memerlukan kesiapan prasarana dan sarana tersendiri dibandingkan dengan pembelajaran tatap muka. Selain memerlukan kehadiran pengajar dan pembelajar melalui media maya (daring) juga diperlukan penguasaan dalam penggunaan teknologi informasi dan komunikasi untuk kegiatan pembelajaran daring. Dalam pembelajaran daring pendidik harus menyiapkan materi pembelajaran daring baik

Silampari Bisa: Jurnal Penelitian Pendidikan Bahasa Indonesia, Daerah, dan Asing Vol. 4, No. 2, 2021 
melalui e-learning, google meet atau melalui WhatsApp. Peserta didik juga perlu belajar dengan mengunduh atau mempelajari materi yang sudah disiapkan atau diunggah pendidik melalui sarana daring tersebut. Artinya, pemanfaatan media pembelajaran online sangat diperlukan dalam sistem pembelajaran daring ini. Sebab, sekalipun pembelajaran dilaksanakan melalui tatapan wajah (seperti melalui zoom meeting) tetapi hanya bersifat tatap maya. Untuk mewujudkan proses pembelajaran daring yang sejajar dengan proses tatap muka dan bahkan lebih baik hasilnya tentu tidak mudah. Namun, berbagai sarana proses pembelajaran dapat dimanfaatkan untuk membekali tersampaikannya materi yang harus dipelajari peserta didik (dalam hal ini mahasiswa calon guru bahasa Indonesia).

Kegiatan pembelajaran keterampilan berbahasa Indonesia juga dapat dilakukan melalui sistem pembelajaran ini, seperti pembelajaran keterampilan berbicara. Pencapaian keterampilan berbicara sebagai bentuk kemahiran berbahasa Indonesia wajib ditempuh mahasiswa calon guru bahasa Indonesia juga secara daring. Untuk mewujudkan proses pembelajaran keterampilan berbicara secara daring maka perlu menggunakan media pembelajaran bahasa lisan seperti penggunaan media video pembelajaran. Untuk itu, media harus dipandang bukan sekedar sebagai alat bantu pembelajaran yang maknanya sebagai penyampai materi tetapi juga sebagai produk kegiatan. Sadiman dkk. (2009:6) mengemukakan sebagai alat bantu pembelajaran, bahwa media pembelajaran juga berarti alat dalam merangsang berpikir dan bertindak dalam belajar secara efektif peserta didik. Untuk menyampaikan pesan informasi pembelajaran dapat menggunakan media teks dan video. Beberapa kelebihan penggunaan video pembelajaran, termasuk pembelajaran praktik berbicara, bahwa: (a) video sebagai wujud praktik penampilan berbicara akan memudahkan pengajar dalam memahami informasi yang disajikan, (b) menyimpan bukti praktik yang perlu dinilai sehingga penilai atau pengajar dapat fokus pada penyajiannya, (c) efisien karena dapat diputar ulang dan efektif untuk menerima pesan informasi yang lengkap, dan (d) dapat mengamati lebih teliti dengan objek audio visual yang disajikan. Secara pedagogi, penggunaan media video pembelajaran dalam mewujudkan praktik pembelajaran keterampilan berbicara menjadi keharusan dalam sistem daring. Dengan kata lain, mahasiswa calon guru bahasa Indonesia harus mampu melaksanakan praktik berbahasa lisan seperti keterampilan berbicara dalam sistem daring ini mulai dari merencanakan pelaksanaan pembelajaran, menyiapkan bahan ajar dan lembar kerja siswa secara daring, menggunakan media daring, dan penilaian secara daring. Cooper (dalam Satori, 2009) menegaskan bahwa sebagai calon pendidik profesional maka mahasiswa harus memiliki konsep pengetahuan dan praktik mengajarkan, penguasaan materi sesuai bidang keilmuannya, dan memiliki keterampilan menyampaikan materi pembelajaran secara baik serta memiliki sikap dan perilaku yang tepat dan bereksistensi.

Keterampilan berbicara merupakan keterampilan berbahasa Indonesia yang paling awal harus dikuasai oleh pembelajar (mahasiswa). Keterampilan berbicara merupakan suatu kecakapan atau kemampuan hasil usaha seseorang dalam proses menuangkan buah pikiran melalui komunikasi dalam bahasa lisan dengan menggunakan kata-kata, kalimat-kalimat yang dirangkai secara lengkap, dan jelas

Silampari Bisa: Jurnal Penelitian Pendidikan Bahasa Indonesia, Daerah, dan Asing Vol. 4, No. 2, 2021 
sehingga dapat dipahami orang lain secara berhasil. Hal ini sebagaimana dikemukakan Rivers (dalam Hadley, 1993:290-292), bahwa kemampuan berbicara merupakan kecakapan seseorang dalam praktik berbahasa lisan secara alamiah dengan memanfaatkan konteks nyata. Keterampilan atau kemampuan ini merupakan upaya seseorang melalui berbagai aktivitas dalam usaha menyelesaikan pekerjaannya. Sedangkan berbicara merupakan proses melafalkan bunyi-bunyi artikulasi untuk menyampaikan ide, gagasan, pikiran, dan pesan agar dapat dipaham isi dan maknanya oleh orang lain melalui rangkaian bahasa lisan (Tarigan, 1983; Haryadi \& Zamzami, 1996). Di sisi lain, Tompkins dan Hoskisson (dalam Rofi'udin \& Zuchdi, 2001:8) mengemukakan proses pembelajaran berbicara dapat dilakukan melalui beberapa jenis kegiatan seperti percakapan, berbicara estetik, berbicara informatik seperti berpidato dan bercerita serta berbicara dramatik. Bercerita sebagai satu jenis keterampilan berbicara yang bertujuan untuk mengungkapkan kemampuan yang bersifat pragmatis lisan dari seseorang (Nurgiyantoro, 2001:278). Disisi lain, Tarigan (1981:35) dan Apriani (2013) menyatakan bahwa bercerita dan berpidato sebagai jenis keterampilan berbicara yang dimaksudkan untuk memberikan informasi kepada orang lain terkait kejelasan makna. Melalui berbagai jenis keterampilan berbicara diharapkan mahasiswa akan dapat mengemukakan pendapat dan meyampaikan informasi serta mengeluarkan gagasan melalui bahasa lisan secara baik. Kemahiran berbicara seseorang yang baik menunjukkan keruntutan pola berpikirnya yang juga baik. Artinya, untuk mewujudkan keterampilan berbicara yang berhasil perlu dilakukan melalui latihan terpadu. Hasil penelitian Purwadi, A. J., \& Yulistio, D. (2020) bahwa keterampilan berbicara dapat dicapai melalui teknik berpidato dan bercerita yang terprogram dengan disertai penyiapan menulis teks pidato dan teks cerita terlebih dahulu. Mahasiswa dapat berhasil dalam berpidato dan bercerita dengan terlebih dahulu menyiapkan teks pidato dan teks cerita sesuai topik tertentu. Berdasarkan teks tertulis tersebut, kemudian mahasiswa mempraktikkannya secara lisan di depan audian.

Namun demikian, dalam situasi dan kondisi saat ini, untuk mewujudkan praktik berbicara dalam proses pembelajaran daring diperlukan media yang relevan. Praktik berbicara menggunakan media video pembelajaran praktik berpidato dan bercerita secara daring lebih tepat digunakan. Pemilikkan keterampilan berbicara di muka umum atau dihadapan audien sangat penting dikuasai mahasiswa calon guru bahasa Indonesia. Sebab, keterampilan ini berguna ketika melakukan interaksi dengan orang lain, seperti untuk menyampaikan pertanyaan dan pendapat serta ketika terjun menjadi pendidik di depan kelas untuk menyampaikan materi pembelajaran yang menjadi tanggung jawabnya. Kenyataan saat ini masih banyak mahasiswa yang belum memiliki keterampilan berbicara ini walaupun mata kuliah, keterampilan berbicara ini sudah dicanangkan dan wajib diambil pada semester dua. Hasil pengamatan peneliti pada kelas berbicara dengan tingkatan yang berbeda mendapati masih banyak mahasiswa yang sulit ketika akan mengemukakan pendapat atau bertanya untuk menyampaikan ide atau gagasan tentang sesuatu menggunakan kalimat yang

Silampari Bisa: Jurnal Penelitian Pendidikan Bahasa Indonesia, Daerah, dan Asing Vol. 4, No. 2, 2021 
runtut dan efektif. Bahkan faktor kebahasaan ini masih belum ditunjang dengan faktor nonkebahasaan yang juga kurang mendukung, seperti kurang keberaniannya untuk berbicara di depan teman-temannya di kelas, tidak percaya diri (self confidance), bahkan tidak menguasai pokok pembicaraan, yang terlihat dari kemampuannya merangkai pilihan kata dalam kalimat secara runtut dan mudah dipahami. Penempatan ide pokok belum tersusun secara baik dan bernalar dalam urutan pembicaraannya. Disamping itu, mahasiswa masih belum tegas dalam melafalkan kata-kata, seperti ketepatan lafal yang masih terbawa lafal kedaerahan serta pilihan kata yang belum mengikuti topik atau tema yang akan disampaikan baik melalui kegiatan berbicara maupun menulis. Hal ini menunjukkan bahwa keterampilan mahasiswa dalam praktik berbahasa lisan perlu diperbaiki, dilatihkan secara terus-menerus agar mencapai hasil yang baik. Penguasaan terhadap beberapa faktor ini akan cepat dicapai apabila mahasiswa memperbaiki pencapaian keterampilan berbicara pada beberapa bidang di atas.

Di antara beberapa bidang keterampilan berbicara yang berperan penting dan perlu diupayakan kualitas pencapaiannya dalam perkuliahan berbicara, seperti keterampilan berpidato dan keterampilan bercerita. Hal ini penting dilakukan karena kedua jenis keterampilan ini melibatkan penguasaan unsur kebahasaan dan nonkebahasaan secara individual. Pada sisi unsur kebahasaan meliputi proses berpikir, bernalar secara runtut, dan penguasaan gagasan, ide pokok, serta isi cerita. Disamping ketepatan lafal dan intonasi serta kemampuan dalam memilih kata dan gaya bahasa baik dalam bercerita maupun dalam berpidato (Yuningsih, 2016). Pada sisi unsur nonkebahasaan kedua jenis keterampilan berbicara tersebut melibatkan secara penuh keberanian untuk tampil di muka umum, ketepatan dalam mimik dan pandangan mata, kepercayaan diri yang tinggi, dan penghayatan isi pesan yang disampaikan (Depdikbud, 1996). Untuk menilai keterampilan berbicara yang mendasarkan pada teknik bercerita dan berpidato dapat digunakan rubrik penilaian dengan memperhatikan unsur kualitas menurut Nurgiyantoro (2001:410) dan Djiwandono (2008), meliputi (1) ketepatan isi cerita, (2) ketepatan penunjukkan detail cerita, (3) ketepatan logika cerita, (4) ketepatan makna seluruh cerita, (5) ketepatan pilihan kata, dan (6) ketepatan kalimat serta (7) kelancaran dalam bercerita. Disamping itu, Hisam (2016) menegaskan bahwa dalam keterampilan berbicara seperti bercerita dan berpidato diperlukan kesiapan seseorang dalam pikiran, kesiapan mental, keberanian, kejelasan lafal dan intonasi sehingga isi cerita (isi pesan pidato) yang disampaikan dapat dengan mudah dipahami oleh orang lain. Dalam pembelajaran keterampilan berbicara perlu pencapaian kompetensi unsur kebahasaan dan nonkebahasaan yang memadai dan serta kepekaan kontekstual yang tinggi. Sebab, berbicara yang sederhana sekalipun tidak mungkin dapat tercapai tanpa menyertakan pengetahuan kaidah kebahasaaan yang juga sederhana dan pemilikan unsur nonkebahasaan yang sudah dilatihkan. Namun, kenyataan menunjukkan, hasil pembelajaran keterampilan berbicara masih jauh dari harapan. Masih banyak mahasiswa yang kurang mampu menguasai topik dalam berbicara secara cepat karena faktor belum memiliki pengalaman kegiatan formal yang memadai dan teknik berbicara yang secara psikologis belum memperhatikan aspek logika berpikir yang sesuai etika,

Silampari Bisa: Jurnal Penelitian Pendidikan Bahasa Indonesia, Daerah, dan Asing Vol. 4, No. 2, 2021 
estetika, dan kesantunan dalam berbicara secara baik. Oleh karena itu, perlu ada upaya secara terus-menerus untuk melatih keterampilan berbicara baik melalui bercerita, berpidato, berdiskusi, dan lainnya di luar perkuliahan keterampilan Berbicara. Walaupun mereka telah mengikuti pelajaran bahasa Indonesia, khususnya keterampilan berbahasa lisan, seperti berbicara sejak sekolah dasar.

Pencapaian kemahiran dalam literasi (kemampuan pemahaman secara lisan dan tulis); berbicara, dan menulis juga harus dibarengi dengan penanaman nilainilai karakter pendidikan pada diri peserta didik. Pelaksanaan Kurikulum 2013 dalam Pembelajaran bahasa Indonesia juga didorong untuk penguasaan nilai-nilai karakter dimaksud. Dalam penguasaan kompetensi inti dan kompetensi dasar, bahwa peserta didik secara langsung dan tidak langsung telah memulai aktivitasnya dengan mempraktikkan nilai-nilai karakter seperti sikap disiplin, yang ditunjukkan dengan hadir ke sekolah tepat waktu atau sebelum jam masuk kelas untuk belajar tiba, bertanggung jawab dalam melakukan perintah penugasan dan menyelesaikan permasalahan materi pembelajaran yang harus diselesaikan, bersikap jujur dengan mematuhi petunjuk mengerjakan atau tidak menyontek, bisa berkolaborasi atau bekerja sama dengan teman sekelas dan mampu menyelesaikan secara mandiri jika tugas harus diselesaikan secara individual, dan penerapan nilai-nilai lainnya. Pencapaian nilai karakter sikap ini didasarkan pada prioritas masing-masing satuan pendidikan (Kementerian Pendidikan Nasional, 2011:7-8). Berkaitan dengan hasil literasi (membaca, berbicara, dan menulis) siswa kita pada pencapaian level PISA bahasa tahun 2012 dengan rata-rata hanya berada pada level 3 berkategori cukup sementara negara lain di Asia Tenggara sudah di atasnya (lihat hasil PISA 2009; 2012). Disamping itu, hasil studi organisasi Internasional, seperti TIMMS, bahwa sebagian besar siswa Indonesia hanya mampu menjawab persoalan pada level menengah (sebanyak 95\%) sedangkan kemampuan siswa dalam menjawab soal yang memerlukan pemikiran masih sangat rendah (hanya 5\%) (Kementerian Pendidikan dan Kebudayaan, 2013:2). Oleh karena itu, tingkat literasi (berpikir cepat) peserta didik kita dalam berbicara dan menulis harus dilakukan pembinaan sebagai upaya menumbuhkan kompetensi dan performansi melalui budaya membaca, berbicara, dan menulis, khususnya mengembangkan hal-hal apa yang dilihat, didengar, dan dipikirkan khususnya dalam menyampaikan informasi sehingga memungkinkan memunculkan ide-ide kritis-kreatif yang dapat dikembangkan dalam bentuk literasi peserta didik untuk dapat menguasai keterampilan berpikir tingkat tinggi.

Kualitas literasi (berpikir) peserta didik yang rendah tidak dapat dipungkiri itu sebagai dampak dari pola pembelajaran bahasa Indonesia yang dipilih guru. Untuk itu, pengembangan kemahiran berbahasa Indonesia lisan melalui keterampilan berbicara perlu dilakukan. Pengembangan keterampilan berbicara merupakan salah satu upaya membina dan mengembangkan pola berpikir peserta didik secara cepat, runtut, kritis, dan kreatif. Keterampilan berbicara berbasis praktik berpidato dan bercerita ini harus dimiliki oleh mahasiswa calon guru bidang studi Pendidikan bahasa Indonesia sebagai model pembelajaran berkomunikasi. Pencapaian kompetensi literasi sesuai kurikulum 2013 sudah dicanangkan sejak sekolah dasar.

Silampari Bisa: Jurnal Penelitian Pendidikan Bahasa Indonesia, Daerah, dan Asing Vol. 4, No. 2, 2021 
Pada tingkat pendidikan ini, peserta didik telah dituntut untuk menyimak, membaca, berdiskusi, memberi komentar, dan menulis kalimat dengan gagasan sederhana dalam urutan yang jelas dan menggunakan kata-kata sendiri. Selain itu, sesuai standar kompetensi lulusan bidang studi bahasa Indonesia, bahwa orientasi literasi berkenaan dengan keterampilan membaca dasar, perpustakaan, media, dan pemanfaatan teknologi informasi komunikasi, dan menulis dalam berbagai konteks dengan tujuan untuk mencapai pembelajaran komunikatif (Bachman, 1990:85). Kemampuan dan kecakapan keterampilan literasi pembelajar akan berdampak pada keterampilan berbicara dan menulis sebagai wujud pencapaian dari keterampilan yang bersifat produktif. Hasil pengamatan terhadap kegiatan keterampilan berbicara baik melalui tugas dan hasil praktik yang dibuat mahasiswa Prodi Pendidikan bahasa Indonesia FKIP Universitas Bengkulu belum memperlihatkan capaian yang nyata sebagai bentuk formal pengukuran tiap-tiap aspek keterampilan tersebut. Artinya, produk kemampuan berbicara harus dinilai sesuai rubrik penilaian masing-masing aspek. Kemampuan menilai ini mesti sudah dimiliki oleh setiap mahasiswa. Oleh karena itu, penelitian ini juga dimaksudkan untuk membekali mahasiswa mempraktikkan aspek keterampilan berbicara secara daring dan cara menilainya sehingga mereka benar-benar memiliki kecakapan dalam praktik baik melalui sistem tatap muka maupun secara daring. Untuk itu, pemilikan keterampilan berbicara mahasiswa bahasa Indonesia secara daring melalui pemanfaatan video pembelajaran praktik berpidato dan praktik bercerita serta pemantauan aktivitas proses pembelajarannya melalui penelitian tindakan kelas penting dilakukan. Untuk memberikan batasan yang jelas terhadap pelaksanaan penelitian maka ruang lingkup penelitian ini dibatasi pada keterampilan berbicara menggunakan teknik berpidato dan bercerita melalui media video pembelajaran secara daring dengan aspek penilaian, mencakup (1) unsur kebahasaan meliputi (a) ketepatan lafal, intonasi, dan jeda, (b) penguasaan gaya bahasa pengucapan dalam bercerita dan berpidato, (c) kesesuaian tema/topik dengan isi, (d) struktur teks dalam cerita dan pidato, (e) ketepatan diksi dan penggunaan kalimat serta keruntutan, (f) kelancaran dalam berbicara; bercerita dan berpidato, dan (2) unsur nonkebahasaan meliputi (a) kepercayaan diri dan keberanian, (b) pengembangan wawasan, (c) penampilan; mimik, pandangan mata, gerak-gerik tubuh, cara berpakaian, dan (3) kualitas video praktik penampilan berpidato dan bercerita (Arsjad \& Mukti U.S., 1988; Mudini \& Purba. 2009).

\section{B. Metode Penelitian}

Penelitian ini menggunakan metode deskriptif dengan pendekatan kuantitatif dan prosedur Penelitian Tindakan Kelas (PTK) model Hopkins. Arikunto dkk. (2012:9) mengemukakan bahwa Penelitian Tindakan Kelas dapat dilaksanakan dalam bentuk siklus yang terdiri dari beberapa tahapan, meliputi tahap perencanaan, tahap pelaksanaan tindakan, tahap pengamatan, dan tahap refleksi. Dalam PTK ini, dilakukan kegiatan (1) tahap perencanaan mencakup: (a) membuat RPS (Rencana Pembelajaran Semester) mata kuliah keterampilan berbicara daring 
menggunakan teknik bercerita dan berpidato melalui video praktik pembelajaran, (b) membuat skenario pembelajaran berbicara daring, (c) menyiapkan alat dan media video praktik pembelajaran berupa teks cerita dan pidato sesuai tema dan memvideokan kegiatan praktiknya, (d) membuat lembar kegiatan perkuliahaan, (e) Membuat pedoman pengamatan aktivitas mahasiswa proses pembelajaran keterampilan berbicara, dan (f) membuat alat penilaian praktik keterampilan berbicara melalui teknik bercerita dan berpidato, (2) tahap pelaksanaan tindakan atau tahap proses pembelajaran meliputi tahap pendahuluan, tahap inti pembelajaran, dan tahap penutup, (3) tahap pengamatan meliputi kegiatan pengamatan proses dan hasil pembelajaran. Khususnya proses berkaitan dengan aktivitas mahasiswa dalam pembelajaran mencakup sikap disiplin, tanggung jawab, kerja sama, kemandirian, dan kejujuran, dan (4) tahap refleksi meliputi penarikan simpulan kegiatan yang sudah dilaksanakan dan yang belum terlaksana dalam upaya memperbaiki kualitas hasil pembelajaran.

Kegiatan PTK ini dilaksanakan dalam dua siklus, setiap siklus dilakukan proses pembelajaran sebanyak 2 kali pertemuan dan 1 kali penilaian proses dan hasil pembelajaran keterampilan berbicara. Siklus I dilaksanakan pada awal bulan April 2021 (minggu pertama dan kedua) dan hasil refleksi pada akhir april 2021 sedangkan siklus II pada awal Mei (minggu pertama dan kedua) dan hasil refleksi akhir Mei 2021 dengan sumber data mahasiswa kelas 2C mata kuliah keterampilan Berbicara semester genap 2020/2021 sebanyak 40 orang. Data penelitian berupa kecakapan penampilan praktik berpidato dan praktik bercerita yang tersimpan dalam video praktik pembelajaran keterampilan berbicara sebanyak 40 produk video praktik berpidato dan video praktik bercerita. Teknik pengumpulan data menggunakan teknik tes penampilan praktik berpidato dan praktik bercerita yang didokumentasikan dalam video praktik pembelajaran. Instrumen penelitian berupa rubrik penilaian praktik penampilan berpidato dan bercerita mahasiswa yang terdiri atas sepuluh aspek penilaian dengan bobot skor 10 setiap aspeknya sehingga skor maksimal 100 sedangkan instrumen pengamatan untuk aktivitas proses pembelajaran mahasiswa dalam perkuliahan di dasarkan pada lima aspek nilai karakter sikap meliputi disiplin, tanggung jawab, bekerja sama (kolaborasi), kemandirian, dan kejujuran. Analisis data utama hasil penelitian menggunakan rumus rerata dan persentase serta hasil akhir dikonfirmasi secara kualitatif untuk menentukan keterampilan berbicara mahasiswa dan aktivitas proses pembelajaran mahasiswa dalam perkuliahan. Indikator pencapaian keberhasilan keterampilan berbicara secara daring dengan praktik berpidato dan praktik bercerita melalui pemanfaatan video praktik pembelajaran ini dinyatakan berhasil apabila mahasiswa secara individual mendapatkan skor lebih dari 75 berkategori baik atau secara klasikan sebanyak $80 \%$ mahasiswa mendapatkan skor lebih dari 75 . Hasil praktik keterampilan berbicara ini harus diikuti dengan aktivitas proses pembelajaran mahasiswa dalam perkuliahan yang minimal berkategori aktif.

Silampari Bisa: Jurnal Penelitian Pendidikan Bahasa Indonesia, Daerah, dan Asing Vol. 4, No. 2, 2021 
Agus Joko Purwadi, Didi Yulistio, Rio Kurniawan

Peningkatan Keterampilan Berbicara Mahasiswa melalui Praktik Berpidato dan Praktik Bercerita Menggunakan Video Pembelajaran Praktik Berbicara

\section{Hasil Penelitian dan Pembahasan \\ 1. Hasil Penelitian}

Penelitian Tindakan Kelas dilakukan sebanyak dua siklus dengan skenario proses pembelajaran setiap siklus dilakukan masing-masing 2 kali pertemuan dengan pertemuan dilaksanakan 2 jam pembelajaran $(2 \times 50$ menit) serta 1 kali pertemuan untuk penilaian proses pembelajaran melalui video sistem tatap maya (zoom meeting dan whatsApp). Hasil pembelajaran keterampilan berbicara mahasiswa program sarjana pendidikan bahasa Indonesia FKIP Universitas Bengkulu secara daring melalui pemanfaatan media video pembelajaran praktik berpidato dan bercerita yang dilengkapi dengan menulis teks pidato dan teks cerita bertema "Menjaga kesehatan." Persiapan teks pidato dan teks cerita ditulis sebelum praktik penampilan berpidato dan bercerita berlangsung (sebagai bahan mengingat konsep-konsep pengetahuan penting dalam memori) yang direkam dalam bentuk media audio visual video Pembelajaranberkategori sangat baik. Hal ini didasarkan pada hasil PTK, penilaian siklus I keterampilan berbicara mahasiswa secara daring dengan menggunakan teknik berpidato dan bercerita berkategori baik dan mengalami peningkatan pada siklus I berkategori sangat baik. Peningkatan keterampilan berbicara ini diikuti dengan meningkatnya aktivitas proses pembelajaran mahasiswa dari kategori aktif menjadi sangat aktif khususnya pada perubahan sikap disiplin, tanggung jawab, bekerja sama, kemandirian, kejujuran dan integritasnya.

\section{a. Pembelajaran Siklus I}

Hasil PTK siklus satu, keterampilan berbicara mahasiswa melalui praktik penampilan berpidato dan bercerita secara daring dilakukan dalam empat tahapan mencakup: (a) tahap perencanaan (plan), menyiapkan proses dan skenario pembelajaran, meliputi (1) menyusun Rencana Pelaksanaan (Perkuliahan) Semester (RPS) materi pembelajaran keterampilan berbicara pokok bahasan (a) menulis teks pidato dan praktik penampilan berpidato dan (b) menulis teks cerita dan praktik penampilan bercerita dengan tema "menjaga kesehatan" serta (c) menyiapkan perangkat (komponen) penilaian praktik berpidato dan bercerita, (2) menyusun materi pembelajaran keterampiran berbicara secara daring dalam power point, (3) menyusun skenario pembelajaran keterampilan berbicara pokok bahasan praktik berpidato dan bercerita secara daring, (4) menyusun media pembelajaran daring dalam bentuk pemanfaatan media video pembelajaran, dan contoh teks cerita dan pidato serta model praktik penampilan berpidato dan praktik penamplan bercerita dan berpidato yang menggunakan video dan dikirimkan oleh setiap mahasiswa secara onlline untuk selanjutnya dinilai oleh dosen pengasuh mata kuliah, (5) menyusun pedoman pengamatan aktivitas proses pembelajaran keterampilan berbicara mahasiswa secara daring, mencakup (a) disiplin, (b) tanggung jawab, (c) kolaborasi, (d) kemandirian, (e) kejujuran, dan (f) integritas, dan (6) menyusun alat penilaian keterampilan berbicara praktik penampilan berpidato dan bercerita secara daring dalam bentuk video prakti pembelajaran yang meliputi 10 aspek/komponen.

Kemudian, (b) tahap pelaksanaan (action), melakukan pemantauan proses pembelajaran sesuai dengan perangkat pembelajaran yang telah disusun pada

Silampari Bisa: Jurnal Penelitian Pendidikan Bahasa Indonesia, Daerah, dan Asing Vol. 4, No. 2, 2021 
tahap perencanaan. Pelaksanaan proses dan skenario pembelajaran dilakukan sebanyak dua kali pertemuan sesuai tahapan pembelajaran, yakni (1) tahap pendahuluan, (2) tahap inti pembelajaran, dan (3) tahap penutup. Pada pelaksanaan kegiatan pembelajaran ini dosen terlebih dahulu menyiapkan sarana pembelajaran daring melalui zoom meeting. Setelah mahasiswa dan dosen berada dalam satu sistem pembelajaran zoom meeting maka proses pembelajaran dimulai sesuai tahapan proses pembelajaran, yakni dosen memulai tahap pendahuluan, dengan membuka pembelajaran, dosen mengucapkan salam, menyampaikan tujuan dan pokok materi perkuliahan yang akan dicapai, khususnya materi pembelajaran keterampilan berbicara, yakni menulis teks dan praktik penampilan berpidato dan bercerita secara daring dengan menggunakan media video praktik pembelajaran. Pada tahap inti pembelajaran pertemuan satu, pembelajaran dimulai dengan dosen menjelaskan materi pembelajaran dan mahasiswa mengamati, bertanya, memberikan contoh menulis teks cerita dan teks pidato serta mahasiswa menulis teks cerita dan teks pidato berdasarkan tema yang telah ditentukan. Pada kegiatan proses pembelajaran (inti) pertemuan kedua, dosen memberikan contoh atau model pjraktik penampilan dalam berpidato dan bercerita khususnya dalam memvideokan praktik berpidato dan bercerita setiap individu sehingga tidak tampil tatap muka atau tatap maya langsung tetapi praktik berpidato dan berceritanya dibuat dalam bentuk media AU video praktik pembelajaran yang selanjutnya dikirimkan kepada dosen pengampu mata kuliah berbicara untuk dinilai dan hasil penilaiannya disampaikan kepada mahasiswa untuk memperbaiki kekurangan dan hal yang perlu ditingkatkan kualitasnya. Selanjutnya, dosen meminta mahasiswa mencoba berlatih dengan mempraktikkan kegiatan bercerita dan berpidato yang direkam menggunakan kamera video oleh teman kerjanya. Kegiatan tahap penutup pembelajaran dilakukan dosen dan mahasiswa dengan menyimpulkan isi proses pembelajaran, melakukan refleksi materi yang sudah disampaikan dan yang belum tersampaikan, memberi tugas latihan praktik berpidato dan bercerita dan mengakhiri pembelajaran dengan salam. Pada akhir tahap tindakan, yakni pada pertemuan ketiga pembelajaran dilakukan penilaian praktik penampilan berpidato dan bercerita melalui pemanfaatan video praktik pembelajaran. Dosen menunjukkan cara menilai video praktik yang sudah diserahkan mahasiswa sebagai contoh menggunakan pedoman penilaian yang sudah disiapkan dan menyampaikan hasil akhirnya kepada semua mahasiswa agar bisa merefleksi selanjutnya.

Tahap selanjutnya, (c) tahap pengamatan (observe), dosen bersama mitra melakukan proses pembelajaran keterampilan berbicara dan melakukan pengamatan terhadap perubahan aktivitas mahasiswa dalam proses pembelajaran menggunakan pedoman pengamatan (lembar observasi). Pengamatan aktivitas mahasiswa dimulai dari awal hingga akhir proses pembelajaran keterampilan berbicara, khususnya berkaitan dengan perubahan sikap disiplin dalam kehadiran, tanggung jawab mahasiswa dalam penyelesaian tugas perkuliahan, cara bekerja sama (berkolaborasi) dengan sesama mahasiswa dalam kelas atau kelompok untuk menyelesaikan permasalahan bersama, sikap secara individu (kemandirian)

Silampari Bisa: Jurnal Penelitian Pendidikan Bahasa Indonesia, Daerah, dan Asing Vol. 4, No. 2, 2021 
dalam menyelesaikan tugas perkuliahan secara baik dan tepat, dan kejujuran dalam proses pembelajaran, serta integritasnya dalam menanggapi permasalahan untuk kepentingan bersama dan tujuan pencapaian pendidikan bersama. Pada pertemuan ketiga di tahap pengamatan dosen melakukan penilaian perubahan sikap mahasiswa dan menyampaikan hasilnya untuk perbaikan yang lebih baik, dan (d) tahap refleksi (reflect), dosen dan tim meninjau kembali hal yang sudah dicapai dalam proses pembelajaran dan perubahan proses dan hasil serta perubahan sikap yang terjadi setelah dilakukan tindakan. Sesuai tahapan PTK telah dilakukan (1) perencanaan tindakan yang berkaitan dengan proses pembelajaran keterampilan berbicara mahasiswa secara daring melalui praktik penampilan berpidato dan bercerita, (2) pelaksanaan tindakan pembelajaran keterampilan berbicara mahasiswa secara daring sesuai tahapan pembelajaran hingga mencapai hasil praktik berpidato dan bercerita berkategori baik, (3) pengamatan tindakan berkaitan dengan aktivitas proses pembelajaran mahasiswa telah mencapai hasil kategori aktif dalam perubahan sikap disiplin, tanggung jawab, bekerja sama, kemandirian, kejujuran, dan integritas dalam keterampilan berbicara, dan (4) secara reflektif bahwa pencapaian proses dan hasil pembelajaran keterampilan berbicara secara daring melalui praktik berpidato dan bercerita perlu ditingkatkan lagi. Oleh karena itu, hasil refleksi ini mengisyaratkan bahwa proses pembelajaran keterampilan berbicara perlu dilanjutkan pada siklus II hingga mencapai indikator keberhasilan yang maksimal.

Berdasarkan hasil pelaksanaan tindakan proses pembelajaran keterampilan berbicara yang telah dilakukan sebanyak dua kali pertemuan dan ditindaklanjuti dengan pertemuan ketiga berupa kegiatan penilaian praktik penampilan berpidato dan bercerita secara daring melalui pemanfaatan video praktik pembelajaran berdasarkan teks pidato dan teks cerita yang telah disusun sesuai tema "menjaga kesehatan" secara individu pada siklus ini diperoleh rerata skor berkategori baik (rerata 75,6). Hasil ini diikuti dengan deskripsi aktivitas proses pembelajaran mahasiswa secara daring juga berkategori aktif. Hasil lengkap pembelajaran keterampilan berbicara melalui praktik penampilan berpidato dan bercerita mahasiswa secara daring siklus I sebagaimana tabel berikut ini.

Tabel 1. Data Keterampilan Berbicara melalui Video Praktik Berpidato dan Bercerita Mahasiswa Prodi S-1 Pendidikan Bahasa Indonesia, FKIP Universitas Bengkulu Siklus I

\begin{tabular}{clcccc}
\hline \multirow{2}{*}{ No. } & \multirow{2}{*}{ ASPEK } & \multicolumn{4}{c}{ Skor Siklus I } \\
\cline { 3 - 6 } & & \multicolumn{2}{c}{ Berpidato } & \multicolumn{2}{c}{ Bercerita } \\
\cline { 3 - 6 } & & Rerata & Kat. & Rerata & Kat. \\
\hline 1 & Kesesuaian tema dengan isi cerita dan pidato & 8 & S.Baik & 8 & S.Baik \\
\hline 2 & Ketepatan struktur teks tulis cerita dan pidato & 8 & S.Baik & 8 & S.Baik \\
\hline 3 & Ketepatan pilihan kata, kalimat, dan paragraf & 7,3 & Baik & 7 & Baik \\
\hline 4 & Ketepatan lafal, intonasi, dan jeda & 7 & Baik & 7 & Baik \\
\hline 5 & Kesesuaian gaya pengucapan & 7 & Baik & 7,5 & Baik \\
\hline 6 & Kelancaran dalam bercerita \& berpidato & 7,5 & Baik & 7,5 & Baik \\
\hline 7 & Kepercayaan diri dan keberanian & 7,3 & Baik & 8 & S.Baik \\
\hline 8 & Kesesuaian pengembangan wawasan & 7,5 & Baik & 7,5 & Baik \\
\hline 9 & Penampilan; mimik, gerakan, dan pakaian & 8 & S.Baik & 7,7 & Baik \\
\hline 10 & Kualitas video praktik penampilan & 7,8 & Baik & 7,6 & Baik \\
\hline
\end{tabular}

Silampari Bisa: Jurnal Penelitian Pendidikan Bahasa Indonesia, Daerah, dan Asing Vol. 4, No. 2, 2021 
Agus Joko Purwadi, Didi Yulistio, Rio Kurniawan

Peningkatan Keterampilan Berbicara Mahasiswa melalui Praktik Berpidato dan Praktik Bercerita Menggunakan Video Pembelajaran Praktik Berbicara

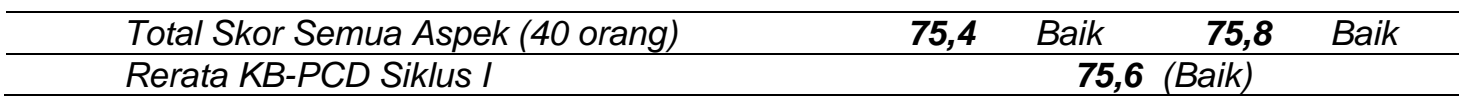

Berdasarkan tabel data di atas dapat dikemukakan bahwa keterampilan berbicara menggunakan video praktik berpidato dan bercerita secara daring mahasiswa berkategori baik (rerata skor 75,6). Hal ini menunjukkan bahwa keterampilan berbicara melalui video praktik berpidato dan bercerita daring mahasiswa pada siklus satu masih memerlukan upaya peningkatan dalam proses dan hasil pembelajarannya. Sebab, hasil masing-masing praktik penampilan baik berpidato maupun bercerita masih sama-sama homogen dalam kategori baik, hasil praktik berpidato dengan skor sebesar 75,4 sedangkan hasil praktik bercerita dengan skor sebesar 75,8. Dari sepuluh kriteria yang dijadikan komponen penilaian hanya beberapa kriteria yang menonjol yakni aspek relevansi isi dengan tema dan struktur teks yang berkategori sangat baik (rerata skor sebesar 8) pada kedua hasil penampilan praktik. Disamping itu, terdapat hasil praktik penampilan berpidato aspek penampilan: mimik, gerakan tubuh, dan pakaian berkategori sangat baik (rerata skor sebesar 8) sedangkan hasil praktik penampilan bercerita aspek kepercayaan diri dan keberanian juga berkategori sangat baik (retata skor sebesar 8). Selebihnya, hasil praktik penampilan mahasiswa pada kedua teknik untuk aspek lain masih berkategori baik. Oleh karena itu, pencapaian hasil keterampilan berbicara siklus satu ini belum mencapai indikator keberhasilan yang dipersyaratkan secara maksimal. Hasil ini diperkuat dengan deskripsi persentase frekuensi dan kategori yang diperoleh mahasiswa secara individual sebagaimana tabel berikut ini.

Tabel 2. Frekuensi Keterampilan Berbicara Menggunakan Video Praktik Berpidato dan Praktik Bercerita Mahasiswa secara Daring pada Siklus I

\begin{tabular}{|c|c|c|c|c|c|c|}
\hline \multirow{2}{*}{ No. } & \multirow{2}{*}{ Kategori } & \multicolumn{2}{|c|}{ Berpidato } & \multicolumn{2}{|c|}{ Bercerita } & \multirow{2}{*}{$\begin{array}{c}\text { Rerata } \\
(\%)\end{array}$} \\
\hline & & Frek & $\%$ & Frek & $\%$ & \\
\hline 1 & Sangat Baik & 0 & 0 & 1 & 2,5 & 1,25 \\
\hline 2 & Baik & 38 & 95 & 36 & 90 & 92,5 \\
\hline 3 & Cukup & 0 & 0 & 2 & 5 & 2,5 \\
\hline 4 & Kurang & 1 & 2,5 & 1 & 2,5 & 2,5 \\
\hline \multirow[t]{2}{*}{5} & Sangat Kurang & 1 & 2,5 & 0 & 0 & 1,25 \\
\hline & Jumlah mhs & 40 & 100 & 40 & 100 & 100 \\
\hline
\end{tabular}

Secara umum pada siklus satu, capaian keterampilan Berbicara mahasiswa yang memanfatakan video praktik berpidato dan bercerita berada pada rerata capaian yang sama, berkategori baik sebesar 92,5\%. Secara khusus, capain keteramplan berbicara melalui praktik berpidato berkategori baik sebanyak 38 orang (95\%), berkategori kurang dan sangat kurang masing-masing sebanyak 1 orang (5\%), serta kategori cukup dan sangat baik tidak ada sedangkan capaian melalui praktik bercerita berkategori sangat baik sebanyak 1 orang $(2,5 \%)$, kategori baik sebanyak 36 orang (90\%), kategori cukup sebanyak 2 orang (5\%), dan katogori kurang sebanyak 1 orang $(2,5 \%)$ sedangkan kategori sangat kurang tidak ada. Hasil ini menunjukkan bahwa keterampilan berbicara mahasiswa belum mencapai hasil maksimal. Data frekuensi keterampilan berbicara melalui video

Silampari Bisa: Jurnal Penelitian Pendidikan Bahasa Indonesia, Daerah, dan Asing Vol. 4, No. 2, 2021 
Agus Joko Purwadi, Didi Yulistio, Rio Kurniawan

Peningkatan Keterampilan Berbicara Mahasiswa melalui Praktik Berpidato dan Praktik Bercerita Menggunakan Video Pembelajaran Praktik Berbicara

pembelajaran praktik berpidato dan praktik bercerita secara daring dapat digambarkan pada diagram batang berikut ini.

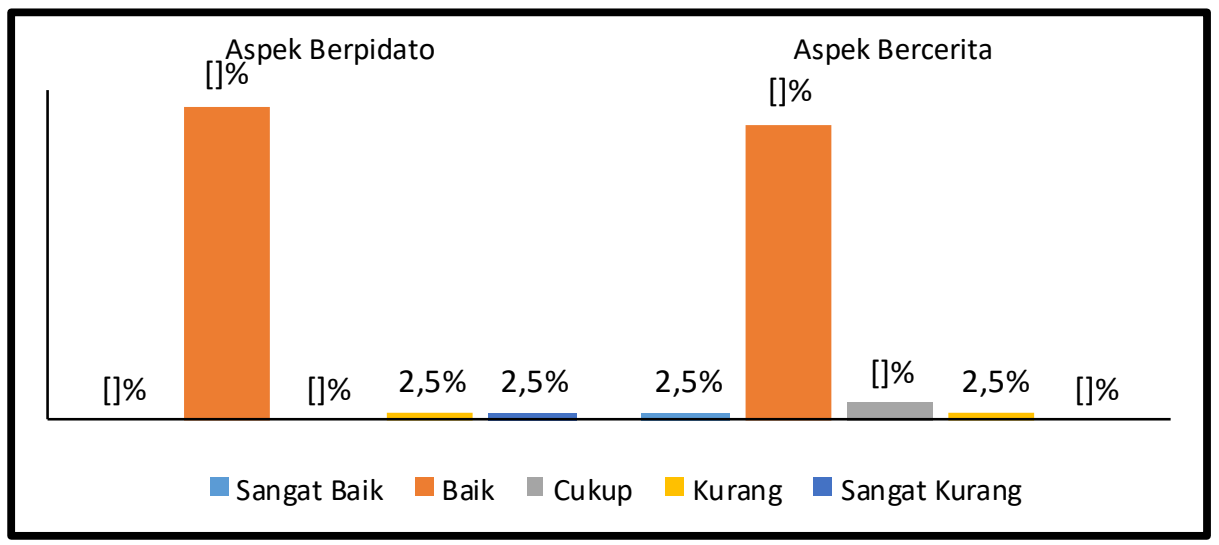

Diagram 1. Frekuensi Keterampilan Berbicara Melalui Video Praktik Berpidato dan Praktik Bercerita Mahasiswa PBI secara Daring pada Siklus I

Dari diagram batang di atas, bahwa capaian keterampilan berbicara melalui aspek praktik berpidato dan aspek praktik bercerita sudah dikuasai secara baik oleh mahasiswa walaupun belum maksimal. Capaian melalui aspek praktik berpidato sebanyak 38 orang (95\%) sudah berkategori baik dan selebihnya masing-masing 1 orang (5\%) berkategori kurang dan sangat kurang sedangkan capaian melalui aspek praktik bercerita sebanyak 1 orang $(2,5 \%)$ berkategori sangat baik, dan sebanyak 36 orang (90\%) sudah berkategori baik, berkategori cukup sebanyak 2 orang (5\%), dan sebanyak 1 orang $(2,5 \%)$ berkategori kurang.

Berdasarkan hasil pengamatan terhadap aktivitas proses pembelajaran keterampilan berbicara melalui pemanfaatan video praktik penampilan berpidato dan bercerita mahasiswa secara daring mencakup lima komponen sikap disiplin, tanggung jawab, kerja sama (berkolaborasi), kemandirian, dan kejujuran diperoleh hasil rerata berkategori aktif. Aktivitas proses pembelajaran mahasiswa terlihat homogen dan merata secara individual dengan hasil tidak berbeda dalam kelima nilai-nilai karakter sikap tersebut sebagaimana digambarkan dalam tabel berikut ini.

Tabel 3. Data Aktivitas Proses Pembelajaran Keterampilan Berbicara Berdasarkan Aspek Sikap Mahasiswa secara Daring pada Siklus I

\begin{tabular}{|c|c|c|c|c|c|c|c|c|c|c|}
\hline \multirow{2}{*}{ No. } & \multirow{2}{*}{ Aspek } & \multicolumn{8}{|c|}{ Aktivitas } & \multirow{2}{*}{ Tot } \\
\hline & & Rerata & Kat & SA & $\%$ & A & $\%$ & $\mathbf{C}$ & $\%$ & \\
\hline 1 & Disiplin & 4,65 & S. Aktif & 27 & 67,5 & 13 & 32,5 & 0 & 0 & 40 \\
\hline 2 & Tanggung Jawab & 4,10 & Aktif & 8 & 20 & 28 & 70 & 4 & 10 & 40 \\
\hline 3 & Kolaborasi & 4,10 & Aktif & 8 & 20 & 28 & 70 & 4 & 10 & 40 \\
\hline 4 & Kemandirian & 4,18 & Aktif & 9 & 22,5 & 28 & 70 & 3 & 7,5 & 40 \\
\hline \multirow[t]{3}{*}{5} & Kejujuran & 4,38 & Aktif & 14 & 35 & 26 & 65 & 0 & 0 & 40 \\
\hline & Total & 21,41 & & 66 & 165 & 123 & 307,5 & 11 & 27,5 & 500 \\
\hline & Rerata & 4,28 & Aktif & 13,2 & 33 & 24,6 & 61,5 & 2,2 & 5,5 & 40 \\
\hline
\end{tabular}

Keterangan: SKS=Sangat Kurang Aktif, KA=Kurang Aktif, $\boldsymbol{C A}=$ Cukup Aktif, $\boldsymbol{A}=$ Aktif, $\boldsymbol{S A}=$ sangat aktif.

Aktivitas proses pembelajarn keterampilan berbicara melalui video pembelajaran baik dalam praktik berpidato maupun praktik bercerita secara daring

Silampari Bisa: Jurnal Penelitian Pendidikan Bahasa Indonesia, Daerah, dan Asing Vol. 4, No. 2, 2021 
pada siklus satu berkategori aktif (rerata skor 4,28). Aspek sikap disiplin berkategori sangat aktif (rerata skor 4,65) dengan jumlah mahasiswa yang berkategori sangat aktif sebanyak 27 orang (\%) dan kategori aktif sebanyak 13 orang $(\%)$ dan selebihnya aspek tanggung jawab, kolaborasi, kemandirian, dan kejujuran berkategori aktif. Hal ini relevan dengan hasil penilaian keterampilan berbicara mahasiswa yang berkategori baik. Artinya, proses pembelajaran keterampilan berbicara perlu ditingkatkan capaiannya agar relevan dengan batas minimal indikator keberhasilan yang ditetapkan. Hasil ini diperkuat dengan deskripsi persentase frekuensi dan kategori aktivitas proses pembelajaran mahasiswa secara individual sebagaimana tabel berikut ini.

Tabel 4. Frekuensi Aktivitas Proses Pembelajaran Keterampilan Berbicara Berdasarkan Deskripsi Kategori Mahasiswa Secara Daring Siklus I

\begin{tabular}{clcc}
\hline \multirow{2}{*}{ No. Kategori } & \multicolumn{2}{c}{ Aktivitas } \\
\cline { 3 - 4 } & & $\mathbf{F}$ & $\%$ \\
\hline 1 & Sangat Aktif & 9 & 22,5 \\
\hline 2 & Aktif & 30 & 75 \\
\hline 3 & Cukup Aktif & 1 & 2,5 \\
\hline 4 & Kurang Aktif & 0 & 0 \\
\hline 5 & Sangat Kurang Aktif & 0 & 0 \\
\hline & Jumlah mhs & 40 & 100 \\
\hline
\end{tabular}

Dari daftar di atas dapat diketahui bahwa aktivitas mahasiswa yang mencakup lima aspek sikap dalam proses pembelajaran keterampilan berbicara berada pada kategori Aktif sebanyak 30 orang (75\%), kategori Sangat Aktif sebanyak 9 orang (22,5\%), dan kategori Cukup Aktif sebanyak 1 orang (2,5\%). Deskripsi capaian persentase frekuensi sesuai kategori aktivitas proses pembelajaran keterampilan berbicara mahasiswa sebagaimana digambarkan dalam diagram batang berikut ini.

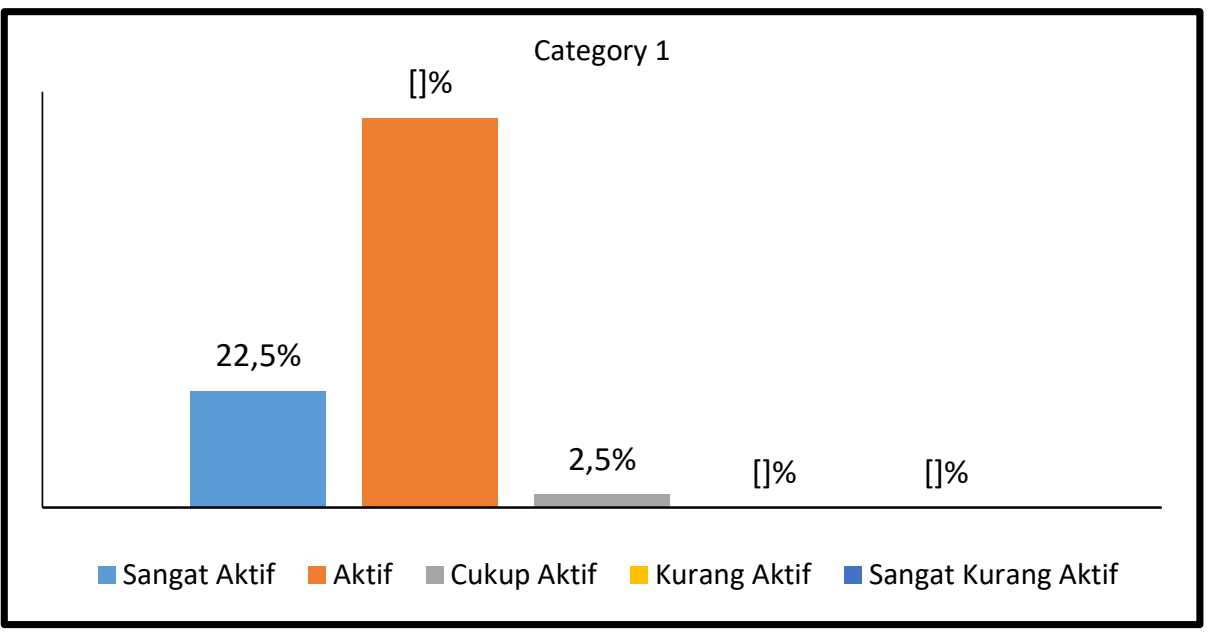

Diagram 2. Pencapaian Aktivitas Proses Pembelajaran Keterampilan Berbicara Secara Daring Mahasiswa Berdasarkan Persentase Frekuensi pada Siklus I

Silampari Bisa: Jurnal Penelitian Pendidikan Bahasa Indonesia, Daerah, dan Asing Vol. 4, No. 2, 2021 
Deskripsi Pencapaian aktivitas proses pembelajaran keterampilan berbicara mahasiswa yang menggunakan video praktik berpidato dan praktik bercerita pada siklus I secara umum berkategori aktif. Hal ini didasarkan pada besar frekuensi kategori sangat aktif sebanyak 9 orang (22,5\%), kategori aktif sebanyak 30 orang $(75 \%)$, dan kategori cukup sebanyak 1 orang (2,5\%). Sehingga secara rerata capaian termasuk berkategori aktif atau belum mencapai indikator keberhasilan dan perlu ditindaklanjuti dengan siklus berikutnya.

\section{b. Pembelajaran Siklus II}

Hasil PTK siklus dua, keterampilan berbicara mahasiswa melalui praktik penampilan berpidato dan bercerita secara daring yang memanfaatkan media video praktik pembelajaran berkategori sangat baik. Prosedur PTK juga dilaksanakan melalui empat tahapan. Keempat tahapan ini mencakup: (a) tahap perencanaan (plan), dilakukan persiapan pembelajaran yang sifatnya melengkapi kekurangan dari kegiatan yang sama siklus satu sebelumnya. Kegiatan melengkapi rancangan pembelajaran meliputi (1) memperbaiki RPS materi pembelajaran keterampilan berbicara (a) rancangan menulis teks pidato dan praktik penampilan berpidato, (b) rancangan menulis teks pidato dan praktik penampilan berbicara dengan tema "menjaga kesehatan", dan (c) menyusun 10 komponen penilaian praktik berpidato dan bercerita, (2) memperjelas bahan pembelajaran dalam power point, (3) menyusun skenario pembelajaran keterampilan berbicara pokok materi berpidato dan bercerita, (4) menyusun media pembelajaran dan contoh teks cerita dan pidato serta model tampilan bercerita dan berpidato, (5) memperbaiki pedoman pengamatan aktivitas mahasiswa meliputi sikap (a) disiplin, (b) tanggung jawab, (c) berkolaborasi, (d) kemandirian, dan (e) kejujuran.

Berikutnya, (b) tahap Pelaksanaan (act), melaksanakan proses pembelajaran sesuai dengan perangkat pembelajaran yang telah disusun dan relevan dengan siklus sebelumnya. Proses pembelajaran dilaksanakan sebanyak dua kali pertemuan sesuai langkah-langkah pembelajaran. Pelaksanaan pembelajaran dilakukan melalui tiga tahapan, yakni (1) pendahuluan, (2) proses (inti) pembelajaran, dan (3) penutup. Pada kegiatan tahap pendahuluan, pembelajaran dimulai dengan membuka pembelajaran, dosen mengucapkan salam, menjelaskan materi pembelajaran yang akan dipelajari, khususnya materi pembelajaran keterampilan berbicara menulis dan praktik bercerita serta menulis dan praktik berpidato, dan menyampaikan tujuan pembelajaran yang akan dicapai. Pada kegiatan proses (inti) pembelajaran pertemuan pertama, pembelajaran dimulai dengan dosen menjelaskan materi pembelajaran dan mahasiswa mengamati, bertanya, memberikan contoh teks cerita dan pidato serta mahasiswa menulis teks cerita dan teks pidato berdasarkan tema yang telah ditentukan. Pada kegiatan proses pembelajaran (inti) pertemuan kedua, dosen memberikan contoh atau model penampilan dalam bercerita dan berpidato menggunakan video tanyangan dan selanjutnya dosen meminta mahasiswa mencoba berlatih dengan mempraktikkan kegiatan bercerita dan berpidato yang dinilai oleh tim penelitinya. Kegiatan penutup pembelajaran dilakukan dosen dan mahasiswa merefleksikan proses pembelajaran yang telah dilakukan dengan menyimpulkan materi

Silampari Bisa: Jurnal Penelitian Pendidikan Bahasa Indonesia, Daerah, dan Asing Vol. 4, No. 2, 2021 
pembelajaran dan mengakhiri pembelajaran dengan salam. Hasil proses pembelajaran dua kali pertemuan ditindaklanjuti dengan pertemuan ketiga pada siklus ini dengan kegiatan penilaian praktik penampilan keterampilan berbicara individu secara daring menggunakan video hasil rekaman praktik berpidato dan bercerita susuai tema yang telah ditulis dalam bentuk teks pidato dan teks cerita. Kegiatan praktik ini dinilai oleh dua orang tim peneliti.

Tahap selanjutnya, yaitu (c) tahap pengamatan (observe), dilakukan kegiatan pengamatan proses pembelajaran keterampilan berbicara menggunakan pedoman pengamatan (lembar observasi). Pengamatan dilakukan terhadap perubahan aktivitas mahasiswa secara daring yang mencakup sikap disiplin, tanggung jawab, bekerja sama (kolaborasi), kemandirian, dan kejujuran dalam proses pembelajaran keterampilan berbicara. Hasil pengamatan aktivitas mahasiswa ketika mengikuti proses pembelajaran keterampilan berbicara secara daring diperoleh bahwa aktivitas mahasiswa berkategori sangat aktif dari kelima indikator aspek yang diamati dalam proses pembelajaran. Aktivitas mahasiswa bersifat homogen dan merata secara individual, dan pada (d) tahap refleksi (reflect), dilakukan kegiatan mengurai proses dan hasil pembelajaran keterampilan berbicara secara daring mahasiswa meliputi kegiatan yang sudah dilakukan dan kegiatan yang belum dilakukan serta aktivitas proses pembelajarannya. Hasil refleksi sesuai kegiatan yang sudah dilakukan bahwa pembelajaran keterampilan berbicara yang menggunakan video praktik berpidato dan praktik bercerita mahasiswa secara daring telah terlaksana dan mencapai kategori sangat baik. Hal ini diikuti dengan aktivitas proses pembelajaran keterampilan berbicara mahasiswa yang juga dideskripsikan berkategori sangat aktif secara individual dan klasikal dan telah mencapai indikator keberhasilan. Oleh karena itu, proses pembelajaran keterampilan berbicara tidak perlu dilanjutkan pada siklus berikutnya atau dihentikan karena sudah mencapai hasil yag diharapkan.

Hasil penilaian pembelajaran keterampilan berbicara melalui video pembeljaran praktik berpidato dan praktik bercerita mahasiswa secara daring pada siklus kedua berhasil melampaui batas minimal indikator keberhasilan. Hasil pembelajaran keterampilan berbicara melalui praktik berpidato dan bercerita ini dapat dilihat pada tabel berikut ini.

Tabel 5. Data Keterampilan Berbicara Melalui Video Praktik Berpidato dan Bercerita Mahasiswa Prodi S-1 Pendidikan Bahasa Indonesia FKIP Universitas Bengkulu pada Siklus II

\begin{tabular}{clcccc}
\hline \multirow{2}{*}{ No. Aspek } & \multicolumn{4}{c}{ Skor Siklus II } \\
\cline { 3 - 6 } & & \multicolumn{2}{c}{ Berpidato } & \multicolumn{2}{c}{ Bercerita } \\
\cline { 3 - 6 } & & Rerata & Kat. & Rerata & Kat. \\
\hline 1 & Kesesuaian tema dengan isi (Pidato \& Cerita) & 9 & S. Baik & 9 & S. Baik \\
\hline 2 & Ketepatan struktur teks tulis pidato \& cerita & 9 & S. Baik & 9 & S. Baik \\
\hline 3 & Ketepatan pilihan kata dan kalimat P \& C & 8,5 & S. Baik & 8 & S. Baik \\
\hline 4 & Ketepatan lafal, intonasi, dan jeda & 8,2 & S. Baik & 8,4 & S. Baik \\
\hline 5 & Kesesuaian gaya pengucapan Pidato \& Cerita & 8,5 & S. Baik & 9 & S. Baik \\
\hline 6 & Kelancaran dalam berpidato \& bercerita & 8,2 & S. Baik & 8,5 & S. Baik \\
\hline 7 & Kepercayaan diri dan keberanian & 8,5 & S. Baik & 9 & S. Baik \\
\hline
\end{tabular}

Silampari Bisa: Jurnal Penelitian Pendidikan Bahasa Indonesia, Daerah, dan Asing Vol. 4, No. 2, 2021 
Agus Joko Purwadi, Didi Yulistio, Rio Kurniawan

Peningkatan Keterampilan Berbicara Mahasiswa melalui Praktik Berpidato dan Praktik Bercerita Menggunakan Video Pembelajaran Praktik Berbicara

\begin{tabular}{clcccc}
\hline 8 & Kesesuaian pengembangan wawasan P \& C & 8 & S. Baik & 8,2 & S. Baik \\
\hline 9 & Penampilan; mimik, gerakan, dan pakaian & 8,8 & S. Baik & 8,5 & S. Baik \\
\hline 10 & Kualitas Video praktik penampilan P \& C & 8,5 & S. Baik & 8,8 & S. Baik \\
\hline & Skor rerata Aspek (40 orang) & $\mathbf{8 5 , 2}$ & S. Baik & $\mathbf{8 6 , 4}$ & S. Baik \\
\hline & Rerata KB-PCD Siklus II & \multicolumn{4}{c}{$\mathbf{8 5 , 8}$ (Sangat Baik) } \\
\hline
\end{tabular}

Berdasarkan tabel data di atas dapat dikemukakan bahwa keterampilan berbicara yang menggunakan video praktik pembelajaran berpidato dan bercerita mahasiswa secara daring pada siklus II berkategori Sangat Baik (rerata skor sebesar 85,8). Hal ini menunjukkan bahwa keterampilan berbicara mahasiswa sudah mencapai kualitas maksimal dalam proses dan hasil pembelajarannya. Hal ini didasarkan pada capaian praktik berpidato dan bercerita yang menggunakan video pembrelajaran yakni: (1) praktik berpidato mahasiswa berkategori sangat baik (rerata skor sebesar 85,2), dan (2) praktik bercerita juga berkategori sangat baik (rerata skor sebesar 86,4). Dari sepuluh komponen yang dinilai pada hasil praktik berpidato dan bercerita dalam keterampilan berbicara mahasiswa, semua memperoleh kategori sangat baik dan hasil ini sudah mencapai indikator keberhasilan yang dipersyaratkan. Hasil ini diperkuat dengan deskripsi persentase frekuensi dan kategori capaian mahasiswa secara individual yang secara umum berkategori sangat baik sebagaimana tabel berikut ini.

Tabel 6. Frekuensi Keterampilan Berbicara Menggunakan Video Praktik Berpidato dan Praktik Bercerita Mahasiswa secara Daring pada Siklus II

\begin{tabular}{ccccccc}
\hline \multirow{2}{*}{ No } & \multirow{2}{*}{ Kategori } & \multicolumn{2}{c}{ Berpidato } & \multicolumn{2}{c}{ Bercerita } & \multirow{2}{*}{ Rerata (\%) } \\
\cline { 3 - 6 } & Frekuensi & $\%$ & Frekuensi & $\%$ & \\
\hline 1 & Sangat Baik & 34 & 85 & 36 & 90 & 87,5 \\
\hline 2 & Baik & 4 & 10 & 2 & 5 & 7,5 \\
\hline 3 & Cukup & 0 & 0 & 1 & 2,5 & 1,25 \\
\hline 4 & Kurang & 1 & 2,5 & 1 & 2,5 & 2,5 \\
\hline 5 & Sangat Kurang & 1 & 2,5 & 0 & 0 & 1,25 \\
\hline \multicolumn{2}{r}{ Total } & 40 & 100 & 40 & 100 & 100 \\
\hline
\end{tabular}

Dari tabel frekuensi di atas, bahwa keterampilan berbicara mahasiswa yang dilakukan melalui praktik berpidato dan praktik bercerita pada siklus II berada pada capaian umum sama, yakni pada kategori/kualitas sangat baik dengan tingkat persentase rerata sebesar $87,5 \%$ dan pada ketegori baik dengan tingkat persentase rerata sebesar $7,5 \%$, dan selebihnya kategori dibawahnya tidak berarti karena tidak mempengaruhi capaian umumnya. Secara spesifik individual dan klasikal bahwa capain keterampilan berbicara melalui video praktik berpidato diperoleh sebanyak 34 orang (85\%) berkategori sangat baik dan 4 orang (10\%) berkategori baik, dan kategori kurang dan sangat kurang masing-maing terdapat 1 orang $(5 \%)$, dan melalui video praktik bercerita diperoleh sebanyak 36 orang $(90 \%)$ berkategori sangat baik, berkategori baik sebanyak 2 orang (5\%), dan masingmasing sebanyak 1 orang (5\%) berkategori cukup dan kurang. Hasil ini menunjukkan bahwa keterampilan berbicara mahasiswa melalui pemanfaatan video pembelajaran praktik berpidato dan praktik bercerita sudah mencapai hasil

Silampari Bisa: Jurnal Penelitian Pendidikan Bahasa Indonesia, Daerah, dan Asing Vol. 4, No. 2, 2021 
Agus Joko Purwadi, Didi Yulistio, Rio Kurniawan

Peningkatan Keterampilan Berbicara Mahasiswa melalui Praktik Berpidato dan Praktik Bercerita Menggunakan Video Pembelajaran Praktik Berbicara

maksimal. Dari capaian persentase frekuensi praktik berpidato dan praktik berbicara mahasiswa secara daring di atas dapat digambarkan pada diagram batang berikut ini.

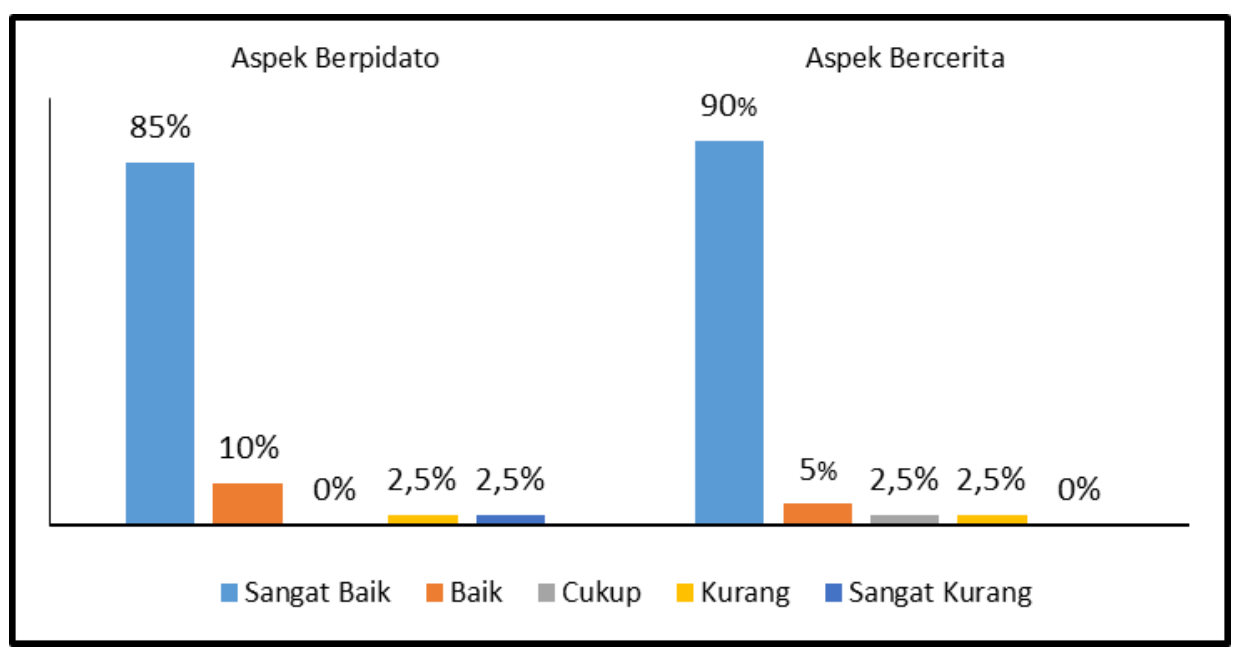

Diagram 3. Pencapaian Persentase Frekuensi Keterampilan Berbicara Mahasiswa

Secara Daring melalui Praktik Bepidato dan Praktik Bercerita pada Siklus II

Deskripsi pada diagram batang di atas menunjukkan, bahwa capaian keterampilan berbicara melalui video praktik berpidato dan praktik bercerita secara daring sudah dikuasai secara sangat baik oleh mahasiswa. Berdasarkan hasil (1) praktik berpidato berkategori sangat baik sebanyak $85 \%$ dan berkategori baik sebanyak $10 \%$ dan selebihnya sebanyak $5 \%$ untuk dua kategori kurang dan sangat kurang, dan juga (2) praktik bercerita yang berkategori sangat baik sebanyak $90 \%$, berkategori baik sebanyak $5 \%$, dan selebihnya sebanyak $5 \%$ untuk dua kategori cukup dan kurang. Hal ini berarti bahwa mahasiswa sudah mencapai batas indikator keberhasilan yang secara individual mencapai nilai lebih dari 75 dan secara klasikal sebanyak $80 \%$ mencapai skor lebih dari 75 . Sebab, sesuai capai tersebut bahwa sebanyak 40 orang mahasiswa sudah mencapai presentase sebesar $87,5 \%$ bahkan berkategori sangat baik.

Hasil pengamatan terhadap aktivitas proses pembelajaran keterampilan berbicara melalui pemanfaatan video pembelajaran praktik berpidato dan praktik bercerita mahasiswa secara daring diperoleh berkategori sangat aktif yang didasarkan pada lima indikator nilai-nilai karakter pendidikan yang diamati, meliputi perubahan sikap disiplin, bertanggung jawab, bekerja sama (berkolaborasi), kemandirian, dan kejujuran dalam pembelajarannya. Aktivitas mahasiswa dalam proses pembelajaran keterampilan berbicara hampir sama capaiannya. Hal ini dapat dilihat dari tabel frekuensi aktivitas proses pembelajaran mahasiswa berikut ini.

Silampari Bisa: Jurnal Penelitian Pendidikan Bahasa Indonesia, Daerah, dan Asing Vol. 4, No. 2, 2021 
Agus Joko Purwadi, Didi Yulistio, Rio Kurniawan

Peningkatan Keterampilan Berbicara Mahasiswa melalui Praktik Berpidato dan Praktik Bercerita Menggunakan Video Pembelajaran Praktik Berbicara

Tabel 7. Data Aktivitas Proses Pembelajaran Keterampilan Berbicara Berdasarkan Aspek Sikap Mahasiswa secara Daring pada Siklus II

\begin{tabular}{|c|c|c|c|c|c|c|c|c|c|c|}
\hline \multirow{2}{*}{ No } & \multirow{2}{*}{ ASPEK } & \multicolumn{8}{|c|}{ Aktivitas } & \multirow{2}{*}{ Tot } \\
\hline & & rerata & Kat & SA & $\%$ & $\mathbf{A}$ & $\%$ & C & $\%$ & \\
\hline 1 & Disiplin & 4,80 & S. Aktif & 33 & 82,5 & 6 & 15 & 1 & 2,5 & 40 \\
\hline 2 & Tanggung Jawab & 4,65 & S. Aktif & 28 & 70 & 10 & 25 & 2 & 5 & 40 \\
\hline 3 & Kolaborasi & 4,70 & S. Aktif & 29 & 72,5 & 10 & 25 & 1 & 2,5 & 40 \\
\hline 4 & Kemandirian & 4,65 & S. Aktif & 28 & 70 & 10 & 25 & 2 & 5 & 40 \\
\hline 5 & Kejujuran & 4,68 & S. Aktif & 27 & 67,5 & 13 & 32,5 & 0 & 0 & 40 \\
\hline & Total & 23,48 & & 145 & 362,5 & 49 & 122,5 & 6 & 15 & 200 \\
\hline & Rerata & 4,72 & S. Aktif & 29 & 72,5 & 9,8 & 24,5 & 1,2 & 3 & 40 \\
\hline
\end{tabular}

Keterangan: SKS=Sangat Kurang Aktif, KA=Kurang Aktif, CA=Cukup Aktif, $\boldsymbol{A}=$ Aktif, $\mathbf{S A}=$ sangat aktif

Aktivitas proses pembelajarn keterampilan berbicara melalui video pembelajaran baik dalam praktik berpidato maupun praktik bercerita secara daring pada siklus dua berkategori sangat aktif (rerata skor 4,72). Secara rinci sesuai aspek yang diamati bahwa aspek sikap (1) disiplin berkategori sangat aktif (rerata skor 4,80 ) dengan jumlah mahasiswa yang berkategori sangat aktif sebanyak 33 orang $(82,5 \%)$ dan kategori aktif sebanyak 6 orang $(15 \%)$ serta kategori cukup sebanyak 1 orang $(2,5 \%)$, (2) tanggung jawab berkategori sangat aktif (rerata skor 4,80 ) dengan jumlah mahasiswa yang berkategori sangat aktif sebanyak 28 orang (70\%) dan kategori aktif sebanyak 10 orang (25\%) serta kategori cukup sebanyak 2 orang (5\%), (3) bekerja sama (berkolaborasi) berkategori sangat aktif (rerata skor $4,70)$ dengan jumlah mahasiswa yang berkategori sangat aktif sebanyak 29 orang $(72,5 \%)$ dan berkategori aktif sebanyak 10 orang $(25 \%)$ serta kategori cukup sebanyak 1 orang (2,5\%), (4) kemandirian berkategori sangat aktif (rerata skor $4,65)$ dengan jumlah mahasiswa yang berkategori sangat aktif sebanyak 28 orang $(70 \%)$ dan berkategori aktif sebanyak 10 orang $(25 \%)$ serta kategori cukup sebanyak 2 orang (5\%), (5) kejujuran berkategori sangat aktif (rerata skor 4,68) dengan jumlah mahasiswa yang berkategori sangat aktif sebanyak 27 orang $(67,5 \%)$ dan berkategori aktif sebanyak 13 orang $(32,5 \%)$ serta selebihnya tidak ada.

Hal ini relevan dengan hasil penilaian keterampilan berbicara mahasiswa yang berkategori sangat baik. Artinya, proses pembelajaran keterampilan berbicara sudah sesuai dengan capaian aktivitiasnya dan telah mencapai batas minimal indikator keberhasilan yang ditetapkan. Hasil ini diperkuat dengan persentase frekuensi dan kategori aktivitas proses pembelajaran mahasiswa secara individual yang secara rerata berkategori sangat aktif sebagaimana tabel berikut ini.

Silampari Bisa: Jurnal Penelitian Pendidikan Bahasa Indonesia, Daerah, dan Asing Vol. 4, No. 2, 2021 
Agus Joko Purwadi, Didi Yulistio, Rio Kurniawan

Peningkatan Keterampilan Berbicara Mahasiswa melalui Praktik Berpidato dan Praktik Bercerita Menggunakan Video Pembelajaran Praktik Berbicara

Tabel 8. Frekuensi Aktivitas Proses Pembelajaran Keterampilan Berbicara Berdasarkan Deskripsi Kategori Mahasiswa Secara Daring pada Siklus II

\begin{tabular}{clcc}
\hline \multirow{2}{*}{ No. } & \multirow{2}{*}{ Kategori } & \multicolumn{2}{c}{ Aktivitas } \\
\cline { 3 - 4 } & & $\mathbf{F}$ & $\%$ \\
\hline 1 & Sangat Aktif & 32 & 80 \\
\hline 2 & Aktif & 7 & 17,5 \\
\hline 3 & Cukup Aktif & 1 & 2,5 \\
\hline 4 & Kurang Aktif & 0 & 0 \\
\hline 5 & Sangat Kurang Aktif & 0 & 0 \\
\hline & Jumlah mhs & 40 & 100 \\
\hline
\end{tabular}

Dari daftar di atas dapat diketahui, bahwa aktivitas mahasiswa dalam proses pembelajaran keterampilan berbicara secara daring yang meliputi lima aspek sikap berada pada kategori sangat aktif sebanyak 32 orang (805\%), kategori aktif sebanyak 7 orang (17,5\%), dan kategori cukup aktif sebanyak 1 orang (2,5\%). Artinya, capaian aktivitas mahasiwa sudah mencapai batas indikator keberhasilan yakni sebanyak 80\% mahasiswa mendapatkan skor lebih dari 75 . Deskripsi capaian aktivitas proses pembelajaran keterampilan berbicara mahasiswa sebagaimana digambarkan dalam diagram batang berikut ini.

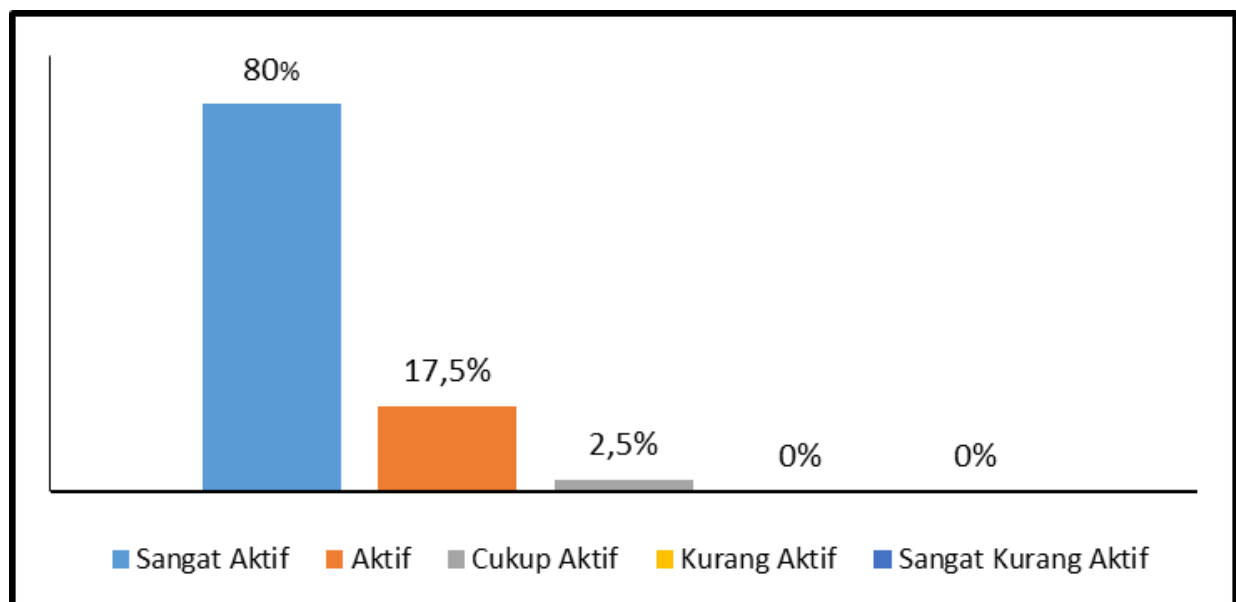

Diagram 4. Pencapaian Aktivitas Proses Pembelajaran Keterampilan Berbicara Secara Daring Mahasiswa Berdasarkan Persentase Frekuensi pada Siklus II

Deskripsi Pencapaian aktivitas proses pembelajaran keterampilan berbicara mahasiswa yang menggunakan video praktik berpidato dan bercerita pada siklus II secara umum berkategori sangat aktif. Hal ini sebagaimana deskripsi dalam diagram batang, bahwa capaian aktivitas proses pembelajaran mahasiswa juga sudah sesuai dengan hasil pembelajaran keterampilan berbicarannya..

Silampari Bisa: Jurnal Penelitian Pendidikan Bahasa Indonesia, Daerah, dan Asing Vol. 4, No. 2, 2021 


\section{Pembahasan}

Berdasarkan hasil PTK diperoleh bahwa terjadi peningkatan hasil pembelajaran keterampilan berbicara yang menfaatkan video pembelajaran praktik berpidato dan praktik bercerita secara daring pada mahasiswa Program S-1 Pendidikan Bahasa Indonesia FKIP Universitas Bengkulu. Peningkatan ini dapat dilihat dari hasil penilaian keterampilan berbicara pada 40 orang mahasiswa pada siklus I berkategori baik (rerata skor sebesar 75,6) mengalami peningkatan pada siklus II menjadi berkategori sangat baik (rerata skor sebesar 85,8). Peningkatan keterampilan berbicara yang memanfaatkan video pembelajaran praktik berpidato dan praktik bercerita ini diikuti dengan meningkatnya aktivitas mahasiswa dalam proses pembelajran keterampilan berbicara yang melibatkan lima aspek perubahan nilai karakter sikap meliputi disiplin, tanggung jawab, bekerja sama (berkolaborasi), kemandirian, dan kejujuran dari kategori aktif pada siklus I meningkat menjadi sangat aktif pada siklus II. Secara khusus, pada siklus satu, bahwa hasil pembelajaran keterampilan berbicara yang memanfaatkan video pembelajaran praktik berpidato berkategori baik (rerata75,4) dan praktik bercerita berkategori baik (erata skor sebesar 75,8 ) mengalami peningkatan pada siklus kedua, dengan hasil keterampilan berbicara yang memanfaatkan video pembelajaran praktik berpidato berkategori sangat baik (rerata sebesar 85,2) dan praktik bercerita berkategori sangat baik (rerata skor sebesar 86,4). Peningkatan keterampilan berbicara melalui praktik berpidato dan bercerita dan ini juga diikuti dengan meningkatnya aktivitas mahasiswa dalam proses pembelajaran yang meliputi pertubahan sikap disiplin, tanggung jawab, bekerja sama, kemandirian, dan kejujuran dari kategori aktif pada siklus I meningkat menjadi sangat aktif pada siklus II. Peningkatan ini sesuai dengan pendapat Rivers (dalam Hadley, 1993) bahwa keterampilan berbicara sebagai kecakapan seseorang dalam praktik berbahasa lisan harus tercermin dari perubahan dalam hal penuangan pikiran dalam pengembangan ide atau gagasan untuk mewujudkan isi pembicaraan, ketepatan pilihan kata, pengunaan kalimat dan paragraf yang runtut, jelas, dan lengkap baik sebagai unsur kebahasaan, dan unsurnonkebahsan serta unur kualitas video pembelajaran yang digunakan baik dalam praktik berpidato maupun dalam praktik bercerita sehingga dapat dipahami isi informasinya oleh pendengar atau audiennya. Hal ini juga berarti bahwa keterampilan berbicara mahasiswa telah mencapai kategori maksimal atau melampaui batasan minimal indikator keberhasilan, yakni melebihi nilai individual lebih dari 75 dan secara klasikal sebanyak $80 \%$ mahasiswa mencapai skor lebih dari 75 sebagai batasan yang ditetapkan.

Pencapaian hasil keterampilan berbicara dengan menggunakan video pembelajaran praktik berpidato dan praktik bercerita secara daring dinilai mengunakan sepuluh komponen keterampilan berbicara secara daring dalam praktik berbahasa lisan tersebut yang mencakup deskripsi penilaian komponen kebahasaan (1) kesesuaian topik dengan isi, (2) ketepatan lafal, intonasi, dan jeda, (3) kesesuaian struktur teks tulis cerita dan pidato, (4) ketepatan pengembangan diksi, kalimat, dan paragraf, (5) ketepatan gaya pengucapan, (6) kelancaran dalam bercerita dan berpidato, dan komponen nonkebahsaan (7) kepercayaan diri dan

Silampari Bisa: Jurnal Penelitian Pendidikan Bahasa Indonesia, Daerah, dan Asing Vol. 4, No. 2, 2021 
keberanian, (8) kesesuaian pengembangan wawasan dalam bercerita dan berpidato, dan (9) penampilan yang mencakup pandangan mata, mimik, gerakan tubuh, dan cara berpakaian, serta komponen kualitas video (10a) kualitas video praktik penampilan berpidato dan (10b) kualitas video praktik penampilan bercerita. Hal ini dibuktikan dari hasil PTK siklus 1 diperoleh skor rerata setiap komponen yang meliputi (1) kesesuaian tema dengan isi, (2) ketepatan lafal, suara, volume intonasi, dan jeda, (3) struktur teks tulisan, (4) pengembangan pilihan kata dan kalimat, (5) gaya pengucapan, (6) kelancaran, (7) kepercayaan diri dan keberanian, (8) pengembangan wawasan, ((9) penampilan mimik, pandangan mata, gerakan badan, dan cara berpakaian, dan (10) kualitas video praktik penampilan untuk praktik berpidato dan berbicara yang masing-masing mencapai kategori baik dan mengalami peningkatan pada hasil PTK siklus II berkategori sangat baik. Hal ini menurut Ross dan Roe (dalam Rofi'udin \& Zuchdi, 2002:13) sudah sangat relevan, bahwa baik praktik berpidato maupun praktik bercerita memiliki karakteristik yang hampir sama, hanya beberapa aspek saja yang agak berbeda seperti aspek struktur teks dan pilihan kata serta kalimatnya. Namun, penting dilakukan dalam upaya meningkatkan keterampilan berbicara seseorang khususnya dalam mendapatkan informasi atau posan secara lisan yang memerlukan penguasaan unsur kebahasaan dan nonkebahasan serta kualitas video untuk praktik daring, seperti penampilannya yang melibatkan cara berbicara, cara berpakaian, cara memandang, dan bahkan cara melangkah atau gerak-gerik anggota tubuh. Dalam hal terkahir pada praktik berbicara (berpidato dan bercerita) ini masih belum sempurna. Artinya, khusus faktor penampilan berbicara mahasiswa perlu terus diperbaiki dan dilatihkan agar menghasilkan model tampilan yang maksimal. Selain itu, juga kualitas video yang perlu lebih halus gambarnya memerlukan keahlian tersendiri dalam editing. Perubahan secara jelas pada siklus dua yang mencapai kategori sangat baik. Hal ini menandakan bahwa mahasiswa telah menguasai keterampilan berbicara khususnya dalam memanfaatkan video pembelajaran praktik berpidato dan praktik bercerita secara daring dan mencapai batasan indikator keberhasilan yang dipersyaratkan.

Di sisi lain, capaian peningkatan keterampilan berbicara pada praktik berpidato dan praktik bercerita melalui pemanfaatan video praktik pembelajaran juga diikuti dengan capaian peningkatan aktivitas proses pembelajaran mahasiswa kategori aktif dari unsur (1) disiplin, (2) tanggung jawab, (3) bekerja sama (berkolaborasi), (4) kemandirian, dan (5) kejujuran pada siklus I dan meningkat secara signifikan berkategori sangat aktif pada siklus II. Hal ini juga berarti bahwa proses pembelajaran keterampilan berbicara yang melibatkan aktivitas mahasiswa juga diikuti dengan hasil pembelajaran keterampilan berbicara secara maksimal. Proses pembelajaran yang tidak dapat dipisahkan dari aktivitas mahasiswa ini berorientasi personal atau prosesnya diamati pada setiap individu mahasiswa. Artinya, aktivitas dalam perkuliahan atau proses pembelajaran yang lebih baik dapat terjadi karena mahasiswa mengikuti aturan. Aktivitas mahasiswa ini telah tercapai sesuai prioritas penerapan beberapa nilai karakter pendidikan. Kegiatan aktivitas proses pembelajaran mahasiswa secara daring ini mengukur lima aspek

Silampari Bisa: Jurnal Penelitian Pendidikan Bahasa Indonesia, Daerah, dan Asing Vol. 4, No. 2, 2021 
nilai sikap, meliputi disiplin, tanggung jawab, kolaborasi, kemandirian, dan kejujuran yang menjadi prioritas penilaian aktivitas proses perkuliahan mahasiswa. Hal ini sebagaimana ditegaskan Kementerian Pendidikan dan Kebudayaan (2013: 8-9), bahwa proses pendidikan karakter peserta didik didasarkan pada totalitas, seluruh potensi individu manusia yang meliputi semua ranah atau domain pembelajaran dengan pencapain nilai-nilai karakter yang terkandung didalamnya dilakukan sesuai prioritas atau sesuai kepentingan proses pembelajaran. Dalam hal ini kelima aspek nilai karakter sikap telah dikuasai secara sangat baik (sangat aktif).

Dalam hal disiplin misalnya akan mendapatkan nilai baik (aktif) apabila hadir tepat waktu, sebelum proses pembelajaran dimulai sudah di ruangan, tanggung jawab akan berkategori baik apabila tugas diselesaikan sesuai ketentuan, dan kemandirian akan baik apabila setelah bekerja bersama-sama teman lain, secara personal dapat mewujudkan dan menyelesaikan pekerjaan yang menjadi tugas dan tanggung jawabnya, seperti menulis teks cerita dan teks pidato serta mempersiapkan penampilan dalam praktik secara peserorangan. Pada aspek kejujuran menunjukkan karakter dan sikap yang benar juga cerminan dari berkata jujur ketika mengatakan sesuatu yang memang harus diucapkan yang sebenarbenarnya. Sebab, jujur akan tampak pada perilaku dan tindakan seseorang yang diiringi dengan niat yang benar dari dalam hatinya. Perbuatan kejujuran paling tidak akan berdampak pada orang lain bahwa perbuatan itu tidak merugikan dan bahkan membuat orang lain senang hatinya. Beberapa sikap yang berkaitan dengan nilainilai karakter mulia seseorang harus dapat diwujudkan dalam perilaku sehari-hari khususnya sebagai bagian dari proses pembelajarn dan pendidikan, Semakin tinggi nilai-nilai karakter pendidikan ini dicapai dan diterapkan serta diwujudkan oleh setiap orang dalam perilakunya maka akan semakin baik pengelolaan proses pembelajaran sehingga upaya ini diharapkan akan meningkatkan kualitas proses dan hasil pembelajaran, khususnya pembelajaran keterampilan berbahasa Indonesia dan pendidikan pada umumnya.

\section{Simpulan dan Saran}

Berdasarkan hasil penelitian dan pembahasan dapat disimpulkan bahwa proses dan hasil pembelajaran keterampilan berbicara yang menggunakan video pembelajaran praktik berpidato dan praktik bercerita secara daring mahasiswa Program S-1 Pendidikan Bahasa Indonesia FKIP Universitas Bengkulu pada siklus I berkategori baik meningkat pada siklus II dengan kategori sangat baik. Hasil ini diikuti dengan perubahan aktivitas proses pembelajaran keterampilan berbicara mahasiswa secara daring pada siklus satu berkategori aktif meningkat pada siklus dua dengan kategori sangat aktif. Artinya, proses pembelajaran keterampilan berbicara dapat dilakukan mahasiswa secara sangat baik sehingga mampu mengubah perilakunya menjadi sangat aktif pada nilai karakter sikap disiplin, tanggung jawab, bekerja sama berkolaborasi) dalam proses penyelesaian masalah, juga memiliki kemandirian, dan kejujuran yang dapat dipercaya dalam proses pembelajaran baik secara individual maupun secara klasikal (bersamasama).

Silampari Bisa: Jurnal Penelitian Pendidikan Bahasa Indonesia, Daerah, dan Asing Vol. 4, No. 2, 2021 
Agus Joko Purwadi, Didi Yulistio, Rio Kurniawan

Peningkatan Keterampilan Berbicara Mahasiswa melalui Praktik Berpidato dan Praktik Bercerita Menggunakan Video Pembelajaran Praktik Berbicara

Berdasarkan simpulan di atas saran untuk peningkatan secara maksimal bagi mahasiswa yakni perlu berlatih lebih banyak dalam praktik berpidato dan praktik bercerita dengan persiapan menulis teks pidato dan teks cerita secara baik serta dalam sistem pembelajaran daring perlu fasilitas penggunaan media video praktik pembelajarann yang juga berkualitas baik.

\section{E. Ucapan Terima Kasih}

Tim penelitian mengucapkan terima kasih kepada pimpinan FKIP Universitas Bengkulu yang telah mendanai kegiatan ini melalui RBA 2021 dan LPPM Universitas Bengkulu yang telah memfasilitasi proses penelitian; persiapan proposal, perizinan, pelaksanaan, dan pelaporan hasil penelitian hingga selesai.

\section{Daftar Pustaka}

Apriani, H. S. (2013). "Pengembangan Keterampilan Berbicara Melalui Teknik Reka Cerita Bergambar Pada Anak TKK". http://www.repository.upi.ed. Diakses 25 April 2018.

Arikunto, S., Suhardjono, \& Supardi. (2012). Penelitian Tindakan Kelas. Jakarta: PT. Bumi Aksara.

Arsjad, M. G., \& Mukti U.S. (1988). Pembinaan Kemampuan Berbicara Bahasa Indonesia. Jakarta: Erlangga.

Bachman, L. F. (1990). Fundamental Considerations in Language Testing. Oxford: Oxford University Press.

Depdikbud. (1996). Pendidikan Keterampilan Berbahasa: Buku Materi Pokok Berbicara. jakarta: Dirjen Dikti Depdikbud.

Djiwandono, S. (2008). Tes Bahasa Pegangan Bagi Pengajar Bahasa. Jakarta: PT Indeks.

Hadley, A. O. (1993). Teaching Language in Context. Boston: Heinle \& Heinle Publishers.

Haryadi \& Zamzami. (1996). Peningkatan Keterampilan Berbahasa Indonesia. Jakarta: Departemen Pendidikan dan Kebudayaan RI.

Hisam. (2016). Bercerita; 10 pengertian Menurut Para Ahli dan (Jenis-ManfaatTujuan). http;www.dosenpendidikan.com. Diunduh 5 Mei 2018.

Silampari Bisa: Jurnal Penelitian Pendidikan Bahasa Indonesia, Daerah, dan Asing Vol. 4, No. 2, 2021 
Agus Joko Purwadi, Didi Yulistio, Rio Kurniawan

Peningkatan Keterampilan Berbicara Mahasiswa melalui Praktik Berpidato dan Praktik Bercerita Menggunakan Video Pembelajaran Praktik Berbicara

Kementerian Pendidikan dan Kebudayaan. (2013). Bahasa Indonesia: Wahana Pengetahuan untuk SMP/MTs Kelas VII. Buku Siswa. Jakarta: Kementerian Pendidikan dan Kebudayaan RI.

Kementerian Pendidikan Nasional. (2011). Panduan Pelaksanaan Pendidikan Karakter. Jakarta: Puskurbuku Balitbang Kemdiknas.

Mudini \& Purba, S. (2009). Pembelajaran Berbicara. Jakarta: Ditjen PMP dan TK P4TK Bahasa, Depdiknas.

Nurgiyantoro, B. (2001). Penilaian dalam Pengajaran Bahasa dan Sastra Edisi ke3. Yogyakarta: PT BPFE.

Purwadi, A. J., \& Yulistio, D. (2020). Peningkatan Keterampilan Berbicara Menggunakan Teknik Bercerita dan Berpidato pada Mahasiswa Program Studi Pendidikan Bahasa Indonesia FKIP Universitas Bengkulu. Silampari Bisa: Jurnal Penelitian Pendidikan Bahasa Indonesia, Daerah, dan Asing, 3(2), 202-223. doi:10.31540/silamparibisa.v3i2.1064

Rofi'udin, A. \& Zuchdi, D. (2001). Pendidikan Bahasa dan Sastra Indonesia Kelas Tinggi. Malang: Universitas Negeri Malang.

Sadiman, A. S., dkk. (2009). Media Pendidikan: Pengertian, Pengembangan, dan Pemanfaatannya. Jakarta: Raja Grafindo Persada.

Satori. (2013). “Komponen Kompetensi Profesional Guru”, Pendidikanku: Informasi Pendidikan Terkini. Http://sdnwonoue.blogspot.com/2013/08.html. Diunduh, 27 April 2017.

Tarigan, D, dkk. (1983). Pengembangan Keterampilan Berbicara. Jakarta: Depdikbud.

Tarigan, H. G. (1981). Berbicara Sebagai Suatu Keterampilan Berbahasa. Bandung: Angkasa.

Yuningsih, S. (2016). Bercerita. Http://www.academia.edu.com. Diunduh 5 Mei 2021. 